pag

Business School

WORKING PAPER SERIES

Working Paper

2014-371
Equity Risk Premium and Regional Integration

Mohamed Arouri

Frédéric Teulon

Christophe Rault

http://www.ipag.fr/fr/accueil/la-recherche/publications-WP.html

IPAG Business School

184, Boulevard Saint-Germain

75006 Paris

France

IPAG working papers are circulated for discussion and comments only. They have not been peer-reviewed and may not be reproduced without permission of the authors. 


\title{
Equity Risk Premium and Regional Integration
}

\author{
Mohamed Arouri \\ University of Auvergne - EUM \\ 41 Boulevard F. Mitterrand - B.P. 54 \\ France-63002 Clermont-Ferrand \\ mohamed.arouri@udamail.fr \\ Frédéric Teulon \\ IPAG Business School \\ 184 Boulevard Saint Germain \\ France- 75006 Paris \\ f.teulon@ipag.fr \\ Christophe Rault \\ Laboratoire d'Economie d'Orléans \\ CNRS UMR 7322 \\ Rue de Blois-B.P. 6739 \\ France - 45067 Orléans Cedex 2 \\ chrault@hotmail.com
}

\begin{abstract}
This article contributes to the literature on stock market integration by developing and estimating a capital asset pricing model with segmentation effects in order to assess stock market segmentation and its effects on risk premia at the regional level. We show that the estimated degrees of segmentation vary from one region to anther and over time. Moreover, we establish that compared to developed market regions, emerging market regions have four main dissimilarities: the total risk premiums are significantly higher, more volatile, dominated by regional residual risk factors and reflect mostly regional events. However, in the recent period emerging market regions have become less segmented as a result of liberalization and reforms and the relative magnitude of the premium associated with global factors has increased.

JEL-Code: G150, F360, C320.
\end{abstract}

Keywords: asset pricing, regional integration, equity risk premium.

Notes

Postprint, International Review of Financial Analysis.

Earlier versions of the paper benefited from helpful comments and suggestions from Jørgen Elmeskov, Robert Ford, David Heald, Phil Hemmings, Peter Hoeller, Edouardo Olaberria, Artur Radziwill, Urban Sila, Douglas Sutherland, Jaejoon Woo, Volker Ziemann and participants at the 14th Banca d'Italia Public Finance Workshop on "Fiscal Policy and Growth" in Perugia, an OECD Economics Department seminar and the CESifo Area Conference on Macro, Money and International Finance. The usual disclaimer applies. 


\section{1- Introduction}

Compared to previous works on stock market integration, this article has at least two contributions to the finance literature. First, we extend available theoretical capital asset pricing models (CAPM) for partially integrated markets in order to propose a model that assesses stock market integration at regional level rather than country level. Second, we investigate the effects of changes in market segmentation on risk premia by distinguishing the relative contributions of global risk factors and residual regional risk factors.

It is now well documented that determining the extent to which a national market is integrated into the world stock market is a question which has a decisive impact on a number of issues affecting problems that are addressed by finance theory such as asset pricing and corporate capital budgeting decisions. If capital markets are fully integrated, investors face common and specific risks, but price only common risk factors because specific risk is fully diversified internationally. In this case, the same asset pricing relationships apply in all countries and regions and expected returns should be determined solely by global risk factors. In contrast, when capital markets are segmented the asset pricing relationship varies from one country or region to another and domestic risk factors determine expected returns. When capital markets are partially segmented, investors face both common and specific risks and price them both. In this case, expected returns should be determined by a combination of local, regional and global risk sources (Karolyi \& Stulz, 2002; Kearney \& Lucey, 2004).

Stock market integration dynamic is affected by both institutional and behavioral factors. First, financial integration is a result of economic, institutional and political reform. In particular, integration depends on the ability of global investors to access domestic securities as well as the ability of domestic investors to access foreign investment opportunities. In fact, access to worldwide international investment opportunities and homemade diversification increase the exposition of domestic assets to global risk factors and therefore improve the domestic or regional stock market integration level. Second, behavioral factors such as risk aversion, relative optimism, and information perception may also affect the desire to invest abroad and thus market integration.

In recent decades, barriers to foreign investment have been removed, country funds have been introduced and American depository receipts have been listed in order to 
develop financially integrated stock markets. In fact, a move towards integrated stock markets should lead to a lower cost of capital, greater investment opportunities, and higher savings and growth made possible by international risk sharing (Stulz, 1999; Bekaert \& Harvey, 2003; Carrieri et al., 2007). This process of stock market integration is complex, gradual and takes years (Bekaert \& Harvey, 1995). Most national and regional stock markets should be between the theoretical extremes of strict segmentation (integration zero) and perfect integration; in other words they are partially integrated. Therefore, assessing the degree of market integration is a purely empirical question that can appropriately be addressed only within the context of an international capital asset pricing model.

In the finance literature, there are theoretical domestic asset pricing models in which it is assumed that markets are strictly segmented (Sharpe, 1964; Ross, 1976) and theoretical international asset pricing models in which it is assumed that markets are perfectly integrated (Adler \& Dumas, 1983; Solnik, 1983). However, there are no theoretical international asset pricing models for partially segmented markets, except those developed in the vein of Stulz (1981) and Errunza and Losq (1985) and Arouri et al. (2012). There are, nevertheless, several empirical models of partial segmentation including Bekaert and Harvey (1995), Adler and Qi (2003), Hardouvelis et al. (2006), Carrieri et al. (2007), Lucey and Muckley (2011) and Gupta and Guidi (2012). These models offer a pure econometric combination of local and global risk factors and attempt ad-hoc tests of market integration. Moreover, at the best of our knowledge, all previous works investigate market integration at the individual country level.

Our article contributes to these previous works in two ways. First, we develop an international conditional capital asset pricing model with segmentation effects in order to assess the degree of segmentation and identify the determinants of risk premium and measure their contribution to the formation of the total premium. Our model allows for different market structures (perfect integration, strict segmentation and partial integration). Second, we propose a suitable econometric framework using a multivariate GARCH-in-Mean methodology and estimate our model at the regional level rather than the individual country level. Indeed, little attention has been paid to the dynamics of the integration of emerging market regions into the world market. However, regional cooperation has been intensified in recent years and regional integration has now become an undeniable trend thanks to its theoretical expected advantages. Regional integration may offer to national emerging stock markets ways to overcome some of the 
obstacles constraining their development. Possible benefits associated with regional integration of exchanges are more possibilities of diversification of risks in more efficient and competitive markets, and lower costs. By pooling the resources of fledgling and fragmented capital markets, regionalization could boost liquidity and the ability of these markets to mobilize local and international capital for private-sector and infrastructural development. Investors would gain access to a broader range of shares; issuers would gain access to a larger number of investors. There may also be a role for a well-functioning regional exchange in preventing large capital outflows from the region. Moreover, progress toward integration of capital markets on a regional basis may actually help spur accelerated economic integration goals in other areas. For example, the harmonization of stock market regulations and trading practices that would accompany any regionalization of exchanges could deepen regional integration more broadly in policy areas such as taxation, accounting standards, corporate governance, and legal practices.

The rest of the article is organized as follows. Section 2 introduces the model and the empirical methodology. Section 3 discusses the related previous works. Section 3 presents the data and discusses our major empirical results. Concluding remarks and future extensions are in section 4.

\section{2- The model and empirical methodology}

\section{1- The model}

Unlike previous works, our idea is not to impose a particular form of segmentation such as a tax or another explicit barrier to international investments and derive effects on equilibrium asset returns (Black, 1974; Stulz, 1981; Errunza \& Losq, 1985; Cooper \& Kaplanis, 2000). We rather assume simply that some global investors do not want and/or do not have access to foreign assets as a result of explicit and/or implicit barriers on inflows and/or outflows, barriers which may make markets partially segmented. The available theoretical and empirical models imposing a particular form of segmentation can be viewed as particular cases of our general model. 
Consider a world with $c$ regions ${ }^{4}$ and $l+1$ types of investors. Because of direct and/or indirect barriers, we assume that investors of type $j(j=0,1, \mathrm{~K}, l)$ have no access/or do not want to access to $k_{j}\left(0 \leq k_{j}<c\right)$ assets, i.e. investors of type $j$ access to $c-k_{j}$ assets; they at least access to the assets of their region if their region is strictly segmented. ${ }^{5}$

Denote by $\overline{D_{j}}$ be the $\left(\left(c-k_{j}\right) \times 1\right)$ vector of investor $j$ 's amount (expressed in the reference country currency) invested in the $c-k_{j}$ risky assets to which investors of type $j$ access. We can write this demand as a $(c \times 1)$ vector by setting $D_{j}=J_{j} \overline{D_{j}}$, where $J_{j}$ is a $\left(c \times\left(c-k_{j}\right)\right)$ matrix equal to the $\left(\left(c-k_{j}\right) \times\left(c-k_{j}\right)\right)$ identity matrix augmented by $k_{j}$ zero-lines corresponding to the $k_{j}$ national assets to which investors $j$ have no access. Let $\Omega_{j}$ be the $\left(\left(c-k_{j}\right) \times\left(c-k_{j}\right)\right)$ variance-covariance matrix of the $c-k_{j}$ assets to which investors of type $j$ have access and $\overline{E(R)}$ the $\left(\left(c-k_{j}\right) \times 1\right)$ vector of expected returns on these assets. The maximisation of the utility of investors $j$ subject to their budget constraints leads to the following demand function:

$$
\overline{D_{j}}=\frac{1}{\delta} \Omega_{j}^{-1}(\overline{E(R)}-r \underline{1})
$$

where $\delta$ represents the risk aversion coefficient.

Denote by $n_{j}$ the number of investors of type $j, n=\sum_{j=0}^{l} n_{j}$ the total number of investors, and $S^{\prime}=\left(s_{1}, s_{2}, \mathrm{~K}, s_{C}\right)$ the supply of the $c$ risky assets. Aggregating the demand of assets by all investors and equalizing total demand and total supply lead to the following expression for the expected excess return on the risky assets:

$$
E(R)-r \underline{1}=\left(\frac{\delta}{n} \Omega\right)\left(\Omega^{-1}\left[\sum_{j=0}^{l} \frac{n_{j}}{n} J_{j} \Omega_{j}^{-1} J_{j}^{\prime}\right]^{-1} S\right)
$$

\footnotetext{
${ }^{4}$ For simplicity, we consider one risky asset from each region. However, the number of studied assets does not affect our final results.

${ }^{5}$ Suppose for simplicity that $k_{0}=0$.
} 
Compared to the traditional model, equation (2) shows that because regions are not completely integrated as investors do not access all risky assets, the total supply $S$ is replaced in the equilibrium valuation relation by an adjusted supply function: $\Omega^{-1}\left[\sum_{j=0}^{l} \frac{n_{j}}{n} J_{j} \Omega_{j}^{-1} J_{j}^{\prime}\right]^{-1} S$. Therefore, investors are subject to an altered world market portfolio. The traditional international CAPM continues to hold with regard to this altered portfolio but it does not hold with regard to the actual world market portfolio. By contrast, if regions were perfectly integrated and investors had access to all assets, the supply function would be equal to $S$ and the traditional CAPM will hold with regard to the actual world market portfolio. The greater the segmentation of the market, the greater the difference from $S$ of the supply function used in the equilibrium valuation relation.

Equation (2) can be simplified as follows:

$$
E(R)-r \underline{1}=\frac{\delta}{n} \Omega S+\frac{\delta}{n} \sum_{j=1}^{l} n_{j} \Omega \Phi S
$$

where $\Phi=\left(\sum_{j=1}^{l} n_{j}\left[\left[1-\frac{n_{0}}{n}\right]\left[I-J_{j} \Omega_{j}^{-1} J_{j}^{\prime}\right]^{-1}-I\right]\right)^{-1}$.

Let $C=S^{\prime} \underline{1}$ be the world market capitalization expressed in the reference country currency and $\alpha=\frac{S}{C}$ be the vector of proportions of the $c$ risky assets in the world stock market. Multiply equation (3) by the vector of capitalisations $\left(\alpha^{\prime}\right)$, we obtain the expression of the return on the world market $E\left(R_{W}\right)=\alpha^{\prime} E(R)$ :

$$
E\left(R_{w}\right)-r=\frac{\delta}{n} \sigma_{w}^{2} C+\frac{\delta}{n} \sum_{j=1}^{l} n_{j} \sigma_{w}^{2} \beta^{\prime} \Pi C
$$

where $\Pi=\Psi \alpha$.

By substituting (4) into (3), we obtain: 


$$
E(R)-r \underline{1}=\beta\left(E\left(R_{w}\right)-r\right)+\frac{\sum_{j=1}^{l} n_{j}}{1+\sum_{j=1}^{l} n_{j} \beta^{\prime} \Pi} \frac{E\left(R_{w}\right)-r}{\sigma_{w}^{2}}\left[\Omega \Pi-\sigma_{w}^{2} \beta \beta^{\prime} \Pi\right]
$$

Which can finally leads to our asset pricing model for partially integrated regions:

$$
E(R)-r \underline{1}=\beta\left(E\left(R_{w}\right)-r\right)+\lambda \Omega^{d} \Pi \varphi
$$

where $\varphi=\frac{\sum_{j=1}^{l} n_{j}}{1+\sum_{j=1}^{l} n_{j} \beta^{\prime} \Pi}$ is a parameter reflecting the international stock market structure.

When market segmentation is weak and the number of constrained investors is insignificant, $\varphi \cong 0$. The term $\Omega^{d}=\left[\Omega-\sigma_{w}^{2} \beta \beta^{\prime}\right]$ measures the regional risk unrelated to international portfolio market. In perfectly integrated markets, this risk is not rewarded because it is eliminated by international portfolio diversification. However, equation (6) says that because of stock market segmentation a part of this regional risk is internationally priced. We call this part "undiversifiable regional risk" which, as shown by equation (6), is measured by $V^{\varepsilon}=\Omega^{d} \Pi \varphi$. More interesting, equation (6) shows also that the price of this international undiversifiable regional risk is equal to the world price of market risk $(\lambda)$. In other words, this risk is translated into a risk premium comparable to that required on world market risk.

For a particular domestic region $i$, equation (6) can written as follows:

$$
E\left(R_{i}\right)-r=\lambda \operatorname{Cov}\left(R_{i}, R_{w}\right)+\lambda \omega_{i}^{\varepsilon} \pi_{i} \varphi
$$

where $\omega_{i}^{\varepsilon}=\sigma_{i}^{2}-\beta_{i}^{2} \sigma_{w}^{2}$ is the regional risk unexplained by the model.

\section{2-The empirical methodology}

Under rational expectations, equation (6) can be written as follows: 


$$
R_{i t}-r_{t}=\lambda \operatorname{Cov}\left(R_{i}, R_{w} / \mathrm{I}_{t-1}\right)+\lambda\left(\varphi \pi_{i}\right) \omega_{i t}^{\varepsilon}+\varepsilon_{i t}
$$

where $I_{t-1}$ is the set of information available to investors at time (t-1).

$\varphi \pi_{i}$ measures the proportion of regional risk unexplained by the model $\left(\omega_{i}^{\varepsilon}\right)$ internationally priced because of market segmentation. Intuitively, $\varphi \pi_{i}$ can be seen as a measure of stock market segmentation and should vary between 0 and 1 depending on regional and international market structures. Econometrically, equation (8) can be translated as follows:

$$
R_{i t}-r_{t}=\lambda h_{i w t}+\lambda \theta_{i} h_{i t}^{\varepsilon}+\varepsilon_{i t}
$$

where $h_{i t}^{\varepsilon}=h_{i t}^{2}-\frac{h_{i w t}^{2}}{h_{w t}^{2}}, h_{i j t}$ is the empirical measure of the covariance of the market $i$ and the market $j$ and $h_{i t}^{2}$ is the variance of market $i . \theta_{i}$ is a parameter between 0 and 1 measuring the degree of segmentation of region i into the world market. If $\theta_{i}=0$, the region $i$ is perfectly integrated and thus only global risk is priced. The more $\theta_{i}$ rises, the more the contribution of the undiversifiable regional risk increases and the less market $i$ is integrated.

On the other hand, equation (9) has to hold for every asset including the market portfolio. For an economy with $c$ regions, the following system of pricing restrictions has to be satisfied at any point in time:

$$
\begin{aligned}
& R_{t}-r_{t} \underline{1}=\lambda h_{c t}+\lambda \Theta * q_{t}+\varepsilon_{t} \quad \varepsilon_{t} / \mathrm{I}_{t-1} \sim \mathrm{N}\left(0, \mathrm{H}_{\mathrm{t}}\right) \\
& H_{t}=C^{\prime} C+a a^{\prime *} \varepsilon_{t-1} \varepsilon_{t-1}^{\prime}+b b^{\prime *} H_{t-1}
\end{aligned}
$$

where $q_{t}=D\left(H_{t}\right)-\left(h_{N t} * h_{N t}\right) / h_{N N t}$, and $R_{t}$ denotes the $(c \times 1)$ vector that includes $(c-1)$ risky assets and the world market portfolio. $\mathrm{H}_{t}$ is the $(c \times c)$ conditional covariance matrix of asset returns, $h_{N t}$ is the $N^{\text {th }}$ column of $\mathrm{H}_{t}$ composed of the conditional covariance of each asset with the market portfolio and $h_{N N t}$ the conditional variance of the world market portfolio. $\Theta$ is the $(c \times 1)$ vector of parameters $\theta, q_{t}$ is the $(c \times 1)$ vector on undiversifiable domestic risk, $D\left(H_{t}\right)$ the diagonal components in 
$\mathrm{H}_{t}$ and $(*)$ denotes the Hadamard matrix product. The dynamics of conditional moments are specified by the diagonal multivariate parsimonious GARCH process originally proposed by Ding and Engle (1994) and then generalized by De Santis and Gérard (1997) to accommodate the GARCH-in-Mean effects. $C$ is a $(c \times c)$ lower triangular matrix and $\boldsymbol{a}$ and $\boldsymbol{b}$ are $(c \times 1)$ vectors of unknown parameters.

To avoid incorrect inferences stemming from the misspecification of the conditional density of asset returns the quasi-maximum likelihood (QML) approach of Bollerslev and Wooldridge (1992) is used to estimate equation (10). The Simplex algorithm is used to initialize the process, then the estimation is performed using the BFGS algorithm.

\section{3- Data and empirical results}

\section{1- Data}

In this sub-section, we introduce the data we use in our empirical investigation and show that the data contain features that can be captured with a GARCH model. As the aim of this article is to examine stock market integration at the regional level, we use monthly returns on regional stock indices for eight regions (4 emerging regions: Emerging Markets ASIA, Emerging Markets Europe, Emerging Markets Far-East, Emerging Markets Latin America; and 4 developed regions: Europe, North America, Pacific and AEFE (Europe, Australasia and Far-East)), as well as a value weighted world market index. The sample covers the period from January 1988 to September 2012. All the indices are obtained from Morgan Stanley Capital International (MSCI) and include both capital gains and dividend yields. Returns are computed in excess of the 30-day Eurodollar deposit rate obtained from DataStream and expressed in American dollar. Descriptive statistics for the excess returns are reported in Table 1.

Table 1 reveals a number of interesting facts. Firstly, the relative behavior of emerging region market returns is similar to that reported in past literature: volatility is high, but returns are not necessary large. Latin America has the highest returns and Pacific the lowest ones. Latin America has the highest risk and North America the lowest one. Secondly, the Bera-Jarque test statistic strongly rejects the hypothesis of normally distributed returns, which supports our decision to use QML to estimate and 
test the model. Moreover, there is some evidence of return predictability using previous excess returns in emerging market regions. Finally, the ARCH test shows significant ARCH effects in most cases.

\section{2- Empirical results}

We proceed in three steps. First, we present the model estimates and compute some specification tests. Second, we analyse the implied segmentation degrees. Finally, we examine the contribution of regional risk to total risk premium.

\section{Model estimation}

Since theory predicts that the world price of risk should be the same for each region (Harvey, 1991), we proceed in two steps. Firstly, we estimate the world equation of the system (10). This provides us with estimates of the world price of risk and of the coefficients of the time-varying world variance. We then impose these estimates in the region estimations of system (10). This strategy is also used by Bekaert and Harvey (1995), Hardouvelis et al. (2006), Carrieri et al. (2007) and Arouri et al. (2012) who note that a two-step procedure has the drawback of including sampling error from the first step but it is more in line with the theory and produces more powerful tests. Results are summarized in Table 2.

\section{World market results}

Panel A of Table 2 reports the results for the world market portfolio. The system estimated is the following:

$$
\begin{aligned}
& R_{w}-r_{t}=\lambda h_{w t t}^{2}+\varepsilon_{t} \quad \varepsilon_{t} / \mathrm{I}_{t-1} \sim \mathrm{N}\left(0, h_{\mathrm{t}}\right) \\
& h_{t}^{2}=c+a \varepsilon_{t-1}^{2}+b h_{t-1}^{2}+\zeta_{t}
\end{aligned}
$$

Merton (1980) and Adler and Dumas (1983) show the price of world market risk to be equal to the world aggregate risk aversion coefficient. Since most investors are risk averse, the price of risk must be positive. Our estimation results show that the average price of world market risk is equal to 2.85 and is significant, which is consistent with the findings of earlier studies. Moreover, there is strong evidence that the world market variance dynamics follow a GARCH process. The standardized residuals show no 
significant autocorrelations and the ARCH effect present in world market returns has been sufficiently captured by the model.

\section{Region per region results}

Panel B of Table 2 contains region per region parameter estimates and a number of diagnostic tests for our model. The ARCH and GARCH coefficients are significant for all regions. This is in line with previous results in the literature. The coefficients $\boldsymbol{a}$ are relatively small, which indicates that conditional volatility does not change very rapidly. However, the coefficients $\boldsymbol{b}$ are large, indicating gradual fluctuations over time.

Diagnostics of standardized residuals ${ }^{6}$ show that all indices of kurtosis and the Bera-Jarque statistics are improved relative to the raw returns of Table 1 . The nonnormality in the data is then reduced in all cases and the hypothesis of normality of residual series is accepted in 4 out of 8 cases: EM Asia, EM Far East, AEFE and North America. There are no ARCH effects in the residual series for all regions no residual autocorrelations in most cases. Therefore, the performed estimation sufficiently eliminated the non-normality and autocorrelation observed in the data. Taken together, our results suggest that the specification we use is flexible enough to capture the dynamics of the conditional first and second moments.

\section{Seqmentation analysis}

Panel A of Table 3 contains information regarding the estimated degrees of segmentation from the previous model reported in Table 2. The degree of segmentation should be zero under complete integration and increases with segmentation. As most emerging regions have known an increasing liberalization movement since the end of nineties (Bekaert et al., 2002, 2003, 2005), we report statistics on the estimated segmentation degrees for the entire period as well as for two subperiods: 1988:011999:12 \& 2000:01-2012:09.

Over the entire period, the degrees of segmentation vary from 0.04 for AEFE to 0.39 for EM Europe. As expected, emerging market regions are clearly more segmented form the world market than developed market regions. Among developed regions, Pacific is the most segmented with a degree of segmentation of 0.19 .

\footnotetext{
${ }^{6}$ In the multivariate framework, the joint standardized residuals are given by $\varepsilon_{t}^{s}=H_{t}^{-1 / 2} \varepsilon_{t}$.
} 
Over the subperiod 1988:01-1999:12, the estimated degrees of segmentation are high in most cases and range from 0.46 (EM Far East) to 0.64 (EM Europe) for emerging market regions and from 0.06 (AEFE) to 0.23 (North America) to developed regions.

Over the second subperiod 2000:01-2012:09, all studied regions have become less segmented into the world market. This result corroborates our apriori expectations based on the gradual lifting of foreign ownership restrictions, general liberalization of capital markets, increased availability of ADRs and country funds, better information and investor awareness. Latin America becomes the most integrated emerging region with an estimated degree of segmentation of only 0.16 . The estimated degree of segmentation decreases to 0.20 for EM Asia and EM Europe and 0.21 for EM Far-East. As for the studied developed market regions, the estimated degrees of segmentation are very weak over this sub-period except for Pacific (0.16).

Overall, our findings are close to those obtained by Gerard et al. (2003) and Chelley-Steeley (2004) for Asian emerging markets, Barari (2004) for Latin American markets, Voronkova (2004) for European emerging markets, and Aggarwal and Kyaw (2005) for the NAFTA region.

\section{$\underline{\text { Risk Premium Analysis }}$}

We have shown that most regions are not completely integrated into the world market. Thus, regional risk plays a statistically significant role in determining the equilibrium value of asset returns, especially in emerging market regions. In this subsection, we assess the economic importance of the premium associated with regional risk factors. To this end, we decompose the total premium into two risk premiums: global and regional:

Total premium: $T P_{t i}=\lambda h_{i w t}+\lambda \theta_{i} h_{i t}^{\varepsilon}$

Global premium: $G P_{i t}=\lambda h_{i w t}$

Regional premium: $R P_{i t}=\lambda_{t-1} \theta_{i} h_{i t}^{\varepsilon}$

Panel B of Table 3 summarized the obtained results. Emerging market regions show significantly higher estimated risk premia than developed market regions. Over the entire period, the annualized estimated total risk premia range from $6.29 \%$ (AEFE) to 
15.51\% (Latin America). Regional risk premium is the most important component of total risk premium in all emerging markets regions while its contribution to total premia is weak for developed market regions. The importance of the regional premium varies from a region to another depending on its degree of segmentation and the quantity of its risk undiversifiable internationally. Total risk premia in developed regions are essentially determined by the world market risk as expected given their low levels of segmentation.

When we the compare the subperiods 1988:01-1999:12 and 2000:01-2012:09, one sees that the role of regional risk factors in determining total risk premia remains important but has significantly decreased. This result is expected because we have shown that segmentation has decreased for all studied regions. Thus, at the end of our sample global premium started to play a more significant role in the total risk premium for all studied regions and its weight as percentages of the absolute total premia have increased. These results suggest that global factors are playing an increasing role in pricing emerging market regions. However, there are some important cross-region variations in the relative size and dynamics of global versus local risk premia.

To sum up, our findings suggest that because of market segmentation, the risk premium associated with the regional risk undiversifiable internationally is a statistically and economically significant component of the total risk premium for all the emerging market regions we study. In most cases, the relative importance of this risk premium has decreased in recent years. The well integrated market regions differ from emerging market regions in two major respects: the total risk premiums are significantly smaller and dominated by global factors and international events.

\section{4- Conclusion}

In this article, we developed a capital asset pricing model in order to assess stock segmentation and its effects on risk premia at the regional level. We assume simply that some global investors from different regions do not want and/or cannot have access to foreign assets as a result of explicit and/or implicit barriers on inflows and/or outflows, a situation that may make stock markets partially segmented. We derive a general model that enables us to price assets in dynamic intermediate market structures where markets are not in the extreme states of perfect integration or complete segmentation. We use a multivariate GARCH-in-Mean specification to apply this model for eight regions: 4 
emerging market regions and 4 developed market regions over the period 1988:012012:09.

Our main findings show that the degree of stock market segmentation changes over time and that most studied market regions have become less segmented in the recent period as a result of liberalization and reforms. Our results also show that because of market segmentation, the risk premium associated with the regional residual risk undiversifiable internationally is the most statistically and economically significant component of the total risk premium for all the studied emerging market regions and that the total risk premium reflects mainly regional events. However, the share of the premium associated with global factors has increased in recent years indicating a higher degree of market integration and higher sensitivity to world events. By comparison with emerging market regions, the developed regions we study have four main dissimilarities: the total risk premiums are significantly smaller, less volatile, dominated by global factors and reflect mostly international events. 


\section{REFERENCES}

- Adler M. and B. Dumas (1983), "International Portfolio Selection and Corporation Finance: A Synthesis”, Journal of Finance, n 38, pp. 925-84.

- Adler M. and Qi R. (2003), “Mexico’s Integration into the North American Capital Market”, Emerging Economic Review, 4, pp. 91-120.

- Aggarwal R., and N. A. Kyaw (2005), "Equity market integration in the NAFTA region: Evidence from unit root and cointegration tests”, International Review of Financial Analysis, 14(4), pp. 393-406.

- Afonso, A. and Rault, C. (2009). "Budgetary and external imbalances relationship: a panel data diagnostic”, CESifo Working Paper Series No. 2559.

- Arouri, M., Nguyen, D.K., Pukthuanthong, K., 2012. An international CAPM for partially integrated markets: Theory and empirical evidence. Journal of Banking and Finance 36, 2473-2493.

- Barari M. (2004), "Equity market integration in Latin America: A time-varying integration score analysis”, International Review of Financial Analysis, 13(5), pp. 649-668.

- Bekaert G, Harvey C. R and Lunsdaine (2003), "Dating the Integration of World Equity Markets”, Journal of Financial Economics, 65 (2), pp. 203-248.

- Bekaert G. and C. Harvey (1995), “Time Varying World Market Integration”, Journal of Finance, 50(2), pp. 403-44.

- Bekaert G. and Harvey C. (2003),” Emerging Markets Finance”, Journal of Empirical Finance, 10, pp. 3-55.

- Bekaert G., Harvey C. and LUMSDAINE R. (2002), “The Dynamics of Emerging Market equity Flows”, Journal of International money and Finance, $21: 3$, pp. 295-350.

- Bekaert G., Harvey C. and Ng A. (2005), "Market Integration and Contagion”, Journal of Business, vol. 78, pp. 39-69.

- Black F. (1974), "International Capital Market Equilibrium with Investment Barriers”, Journal of Financial Economics, 1, pp. 337-352.

- Bollerslev T. and Wooldrige J.M. (1992), "Quasi-maximum Likelihood Estimation and Inference in Dynamic Models with Time-Varying Covariances”, Econometric Review, $\mathrm{n}^{\circ} 11$, pp. 143-172.

- Carrieri F., Errunza V. and Hogan K. (2007), “Characterizing World Market Integration Through Time”, Journal of Financial and Quantitative Analysis, 42, 915-940.

- Chelley-Steeley P. (2004), "Equity market integration in the Asia-Pacific region: A smooth transition analysis", International Review of Financial Analysis, 13(5), pp. 621-632

- Cooper I. and Kaplanis E. (2000), "Partially Segmented International Capital Market Integration Budgeting”, Journal of International Money and Finance, 43, pp. 287-307. 
- De Santis G. and Gerard B. (1997), "International Asset Pricing and Portfolio Diversification with Time-Varying Risk”, Journal of Finance 52, pp. 18811912.

- Ding Z. and R. Engle (1994), "Large Scale Conditional Covariances Matrix Modelling, Estimation and Testing”, Working Paper, University of California at San Diego.

- Drine, I. and Rault, C. (2006), "Testing for inflation convergence between the Euro Zone and its CEE partners", Applied Economics Letters, vol. 13, n ${ }^{\circ} 4$, March 2006.

- Drine, I. and Rault, C. (2005), "Can the Balassa-Samuelson theory explain longrun real exchange rate movements in OECD countries?", Applied Financial Economics, 15(8), 519-530.

- Ettunza V. and Losq E. (1985), "International Asset Pricing under Mild Segmentation: Theory and Test“, Journal of Finance 40,pp. 105-24.

- Gerard B., K. Thanyalakpark and J. Batten (2003), “Are the East Asian Markets Integrated? Evidence from the ICAPM”, Journal of Economics and Business, 55, pp. 585-607.

- Gupta R., and Guidi F. (2012), “Cointegration relationship and time varying comovements among Indian and Asian developed stock markets”, International Review of Financial Analysis, 21, pp. 10-22.

- Hardouvelis G., Malliaropoulos G. and D. Priestley (2006), "EMU and Stock Market Integration”, Journal of Business, vol. 79, pp. 365-392.

- Harvey C (1991), “The World Price of Covariance Risk”, Journal of Finance, vol 46(1), pp. 111-57.

- Karolyia A. and R. Stulz, (2002),“Are Financial Assets Priced Locally or Globally?”, in Handbook of the Economics of Finance, Constantinides, Harris and Stulz editions, North-Holland.

- Kearney C., and Lucey B. M. (2004), "International equity market integration: Theory, evidence and implications”, International Review of Financial Analysis, 13(5), pp. 571-583.

- L'Horty, Y. and Rault C. (2004), "Inflation, Minimum Wage and Other Wages: An Econometric Study of French Macroeconomic Data”, Applied Economics 36, No. 4.

- L’Horty Y. and Rault C. (1999), “Les causes du chômage en France: Une réestimation du modèle WS-PS”, CSERC Working papers, n 99-01.

- Lucey B. M., and C. Muckley (2011), "Robust global stock market interdependencies”, International Review of Financial Analysis, 20(4), pp. 215224.

- Merton R. (1980), “On estimating the Expected Return on the Market: An Explonary Investigation”, Journal of Financial Economics, 8(4), pp. 323-361.

- Parent, A., \& C. Rault (2004), “The Influences Affecting French Assets Abroad Prior to 1914”, Journal of Economic History 64(2), 328-62. 
- Ross S. A. (1976), “The Arbitrage Theory of capital Asset Pricing”, Journal of Economic Theory, ${ }^{\circ} 4$, pp.343-362.

- Sharpe W. (1964), "Capital Asset Prices: A Theory of Market Equilibrium under Conditions of Risk”, Journal of Finance, n9, pp.725-742

- Solnik B. (1983), "International Arbitrage Pricing Theory”, Journal of Finance, 38, pp. 449-57.

- Stulz R. (1981), “A Model of International Asset Pricing”, Journal of Financial Economics, n9, p. 383-406.

- Stulz R. (1999), "International Portfolio Flows and Security Markets”, in Martin Feldstein, Ed. International Capital Flows, University of Chicago Press.

- Voronkova S. (2004), "Equity market integration in Central European emerging markets: A cointegration analysis with shifting regimes", International Review of Financial Analysis, 13(5), pp. 633-647. 
$\underline{\text { Table1: }}$

\section{Descriptive statistics of region excess returns}

Annualized monthly equity returns are in US dollar and computed in excess of the 30-day euro-dollar deposit rate. The sample covers the period January 1988 - September 2012. B-J is the Bera-Jarque test for normality based on excess skewness and Kurtosis. Q(6) is the Ljung-Box test for autocorrelation of order 6 for the returns and ARCH(6) is the ARCH test of order 6.

\begin{tabular}{|c|c|c|c|c|c|c|c|c|c|}
\hline & " EM Asia & $\begin{array}{c}\text { EM } \\
\text { Europe }\end{array}$ & $\begin{array}{c}\text { EM Far } \\
\text { East }\end{array}$ & $\begin{array}{c}\text { EM Latin } \\
\text { America }\end{array}$ & 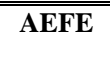 & Europe & $\begin{array}{c}\text { North } \\
\text { America }\end{array}$ & "Pacific & "World \\
\hline Mean & 2.184 & 2.400 & 1.692 & 10.920 & 1.512 & 4.632 & 5.808 & -1.884 & 3.300 \\
\hline Std. Dev. & 25.638 & 32.916 & 27.048 & 32.116 & 17.885 & 18.058 & 15.048 & 20.369 & 15.585 \\
\hline Kurtosis & 4.016 & 5.753 & 4.223 & 6.291 & 4.240 & 4.789 & 4.704 & 3.679 & 4.722 \\
\hline B-J & $26.434^{*}$ & $113.426^{*}$ & $27.751^{*}$ & $197.52 *$ & $37.072 *$ & $66.525 *$ & $65.902 *$ & $8.236 * *$ & $65.992 *$ \\
\hline$Q(6)$ & $24.001^{*}$ & $13.886 * *$ & $21.350 *$ & 5.731 & 4.931 & 8.064 & 6.848 & 4.652 & 5.957 \\
\hline
\end{tabular}


Table 2:

Quasi-maximum likelihood estimates of the model

Panel A reports results for the world market model. The model estimated is:

$$
\begin{aligned}
& R_{w}-r_{t}=\lambda h_{w t t}^{2}+\varepsilon_{t} \quad \varepsilon_{t} / \mathrm{I}_{t-1} \sim \mathrm{N}\left(0, h_{\mathrm{t}}\right) \\
& h_{t}^{2}=c+a \varepsilon_{t-1}^{2}+b h_{t-1}^{2}+\zeta_{t}
\end{aligned}
$$

Panel B reports results for the estimation region per region. The estimated model is:

$$
\begin{aligned}
& R_{t}-r_{t} \underline{1}=\lambda h_{c t}+\lambda \Theta * q_{t}+\varepsilon_{t} \quad \varepsilon_{t} / \mathrm{I}_{t-1} \sim \mathrm{N}\left(0, \mathrm{H}_{\mathrm{t}}\right) \\
& H_{t}=C^{\prime} C+a a^{\prime *} \varepsilon_{t-1} \varepsilon_{t-1}^{\prime}+b b^{\prime *} H_{t-1}
\end{aligned}
$$

where $q_{t}=D\left(H_{t}\right)-\left(h_{N t} * h_{N t}\right) / h_{N N t}$, and $R_{t}$ denotes the $(c \times 1)$ vector that includes $(c-1)$ risky assets and the world market portfolio. $\mathrm{H}_{t}$ is the $(c \times c)$ conditional covariance matrix of asset returns, $h_{N t}$ is the $N^{\text {th }}$ column of $\mathrm{H}_{t}$ composed of the conditional covariance of each region with the market portfolio and $h_{N N t}$ the conditional variance of the world market portfolio. $\Theta$ is the (c $\left.\times 1\right)$ vector of degrees of segmentation, $q_{t}$ is the $(c \times 1)$ vector on undiversifiable regional risk, $D\left(H_{t}\right)$ the diagonal components in $\mathrm{H}_{t}$ and $(*)$ denotes the Hadamard matrix product. $C$ is a $(c \times c)$ lower triangular matrix and a and $\boldsymbol{b}$ are $(c \times 1)$ parameter vectors. $\mathrm{I}_{t-1}$ is the true non observable set of information variables available at $(t-1)$.

Estimates are based on annualised monthly returns expressed in US dollar. Equity returns are computed in excess of the 30-day euro-dollar deposit rate. The sample covers the period January 1988 - September 2012 The models are estimated by Quasi-Maximum Likelihood in two stages. We estimate first the equation for the world index returns (Panel A) and then impose the estimates of the world price of risk and the world variance coefficients in each region estimations (Panel B).

$B-J$ is the Bera-Jarque test for normality based on excess skewness and Kurtosis. Q(6) is the Ljung-Box test for autocorrelation of order 6 for the returns and ARCH(6) is the ARCH test of order 6.

\section{Panel A: Estimation results for the world market}

\begin{tabular}{lc} 
World price of risk & \\
\hline$\lambda$ & $2.854^{* *}$ \\
& $(0.013)$
\end{tabular}

\section{GARCH process}

\begin{tabular}{ll}
\hline & World \\
\hline $\boldsymbol{c}$ & $1.306^{* *}$ \\
& $(0.617)$ \\
\hline $\boldsymbol{a}$ & $0.132^{*}$ \\
& $(0.032)$ \\
\hline $\boldsymbol{b}$ & $0.807^{*}$ \\
& $(0.060)$ \\
\hline
\end{tabular}


Residual diagnostics

\begin{tabular}{lc}
\hline & World \\
\hline Skewness & -0.702 \\
Kurtosis & 4.080 \\
J.B. & $38.878^{*}$ \\
Q(6) & 2.456 \\
ARCH(6) & 0.2165 \\
\hline
\end{tabular}

Panel B: Estimation results region per region

GARCH process

\begin{tabular}{|c|c|c|c|c|c|c|c|c|}
\hline & EM Asia & EM Europe & EM Far East & $\begin{array}{c}\text { EM Latin } \\
\text { America }\end{array}$ & AEFE & Europe & North America & Pacific \\
\hline $\begin{array}{l}a \\
b\end{array}$ & $\begin{array}{c}0.381^{*} \\
(0.126) \\
0.395^{* *} \\
(0.168)\end{array}$ & $\begin{array}{l}0.154^{*} \\
(0.051) \\
0.770^{*} \\
(0.083)\end{array}$ & $\begin{array}{l}0.229 * \\
(0.072) \\
0.704^{*} \\
(0.081)\end{array}$ & $\begin{array}{c}0.117^{*} \\
(0.032) \\
0.845^{*} \\
(0.041)\end{array}$ & $\begin{array}{l}0.064^{* *} \\
(0.036) \\
0.902^{*} \\
(0.058)\end{array}$ & $\begin{array}{l}0.154^{*} \\
(0.051) \\
0.770^{*} \\
(0.083)\end{array}$ & $\begin{array}{l}0.043^{*} \\
(0.017) \\
0.944^{*} \\
(0.078)\end{array}$ & $\begin{array}{c}0.239 * \\
(0.072) \\
0.004 \\
(0.224)\end{array}$ \\
\hline \multicolumn{9}{|c|}{ Residual diagnostics } \\
\hline & EM Asia & EM Europe & EM Far East & $\begin{array}{c}\text { EM Latin } \\
\text { America } \\
\end{array}$ & AEFE & Europe & North America & Pacific \\
\hline Skewness & 0.122 & 0.175 & 0.116 & -0.432 & -0.014 & 0.175 & 0.045 & 0.159 \\
\hline Kurtosis & 2.530 & 3.824 & 2.702 & 3.567 & 3.503 & 3.824 & 3.383 & 4.154 \\
\hline J.B. & 3.460 & $9.940 *$ & 1.768 & $13.238 *$ & 3.153 & $9.940 *$ & 1.922 & $17.745^{*}$ \\
\hline$Q(6)$ & $21.065^{*}$ & 5.175 & $18.402 *$ & 4.466 & 4.495 & 5.175 & 4.730 & 5.757 \\
\hline ARCH(6) & 1.189 & 0.546 & 1.028 & 0.854 & 0.689 & 0.546 & 1.141 & 0.449 \\
\hline
\end{tabular}




\section{Table 3:}

\section{Estimated degrees of segmentation and risk premia analysis}

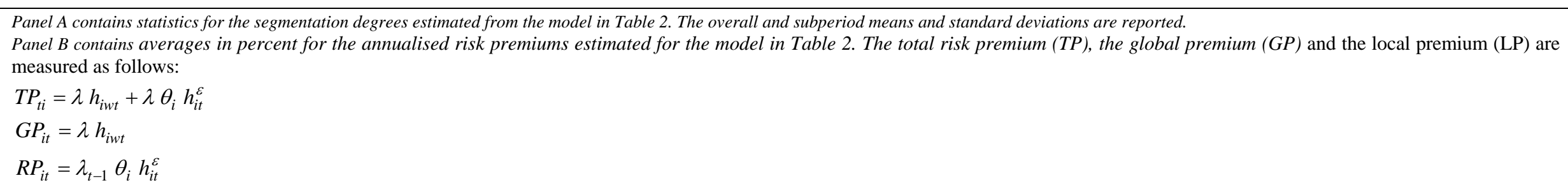

Panel A: Statistics for degrees of segmentation

\begin{tabular}{|c|c|c|c|c|c|c|c|c|}
\hline & EM Asia & EM Europe & EM Far East & EM Latin America & AEFE & Europe & North America & Pacific \\
\hline Overall mean & $0.314 * *$ & $\begin{array}{l}0.389 * \\
(0.112)\end{array}$ & $\begin{array}{l}0.325^{*} \\
(0.089)\end{array}$ & $\begin{array}{l}0.378^{*} \\
(0.073)\end{array}$ & $\begin{array}{c}0.043 \\
(0.032)\end{array}$ & $\begin{array}{c}0.081^{* * *} \\
(0.048)\end{array}$ & $\begin{array}{c}0.102 \\
(0.070)\end{array}$ & $\begin{array}{l}0.190 * \\
(0.062)\end{array}$ \\
\hline Before 2000 & $\begin{array}{l}0.470^{*} \\
(0.112)\end{array}$ & $\begin{array}{l}0.637^{*} \\
(0.098)\end{array}$ & $\begin{array}{l}0.459^{*} \\
(0.109)\end{array}$ & $\begin{array}{l}0.585^{*} \\
(0.154)\end{array}$ & $\begin{array}{c}0.056 \\
(0.041)\end{array}$ & $\begin{array}{c}0.147^{* * *} \\
(0.081)\end{array}$ & $\begin{array}{l}0.225^{* *} \\
(0.110)\end{array}$ & $\begin{array}{c}0.169^{* *} \\
(0.085)\end{array}$ \\
\hline After 2000 & $\begin{array}{l}0.195^{* *} \\
(0.078)\end{array}$ & $\begin{array}{l}0.198 * * \\
(0.085)\end{array}$ & $\begin{array}{l}0.205^{*} \\
(0.069)\end{array}$ & $\begin{array}{l}0.155^{* *} \\
(0.074)\end{array}$ & $\begin{array}{c}0.034 * * * \\
(0.019)\end{array}$ & $\begin{array}{c}0.042^{* * *} \\
(0.025)\end{array}$ & $\begin{array}{c}0.025 \\
(0.510)\end{array}$ & $\begin{array}{r}0.163 * * \\
(0.096)\end{array}$ \\
\hline
\end{tabular}

Panel B: Analysis of risk premia

\begin{tabular}{|c|c|c|c|c|c|c|c|c|c|}
\hline & TP & GP & RP & 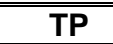 & GP & RP & TP & GP & RP \\
\hline & \multicolumn{3}{|c|}{ All sample } & \multicolumn{3}{|c|}{ Before December 2000} & \multicolumn{3}{|c|}{ After December 2000} \\
\hline$\overline{\text { EM Asia }}$ & $111,232^{*}$ & "5,341* & 5,891* & 10,756* & $3,755^{*}$ & $77,001^{\star}$ & 12,053* & 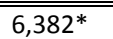 & $\begin{array}{l}5,671^{*} \\
\end{array}$ \\
\hline EM Europe & $12,350 *$ & $4,327^{*}$ & $8,023^{*}$ & $13,042^{*}$ & $2,826^{*}$ & $10,216^{*}$ & $11,630^{*}$ & $4,487^{*}$ & $7,143^{*}$ \\
\hline EM Far East & $12,516^{*}$ & $5,735^{*}$ & $6,781^{*}$ & $14,375^{*}$ & $3,831 *$ & $10,544^{*}$ & $10,856^{*}$ & $5,633^{*}$ & $5,222^{*}$ \\
\hline $\begin{array}{l}\text { EM Latin } \\
\text { America }\end{array}$ & $15,511^{*}$ & $4,407^{*}$ & $11,104^{*}$ & $15,525^{*}$ & $3,531 *$ & $11,994^{*}$ & $15,422^{*}$ & $8,073^{*}$ & $7,350 *$ \\
\hline AEFE & $6,289 *$ & $5,896^{*}$ & 0,394 & $5,846^{*}$ & $5,280^{*}$ & 0,565 & $7,329 *$ & $6,304 *$ & $1,025 * * *$ \\
\hline Europe & $6,612^{*}$ & $5,856^{*}$ & $0,756 * * *$ & $6,016^{*}$ & $5,379^{*}$ & $0,637^{* *}$ & $7,367^{*}$ & $6,222^{*}$ & $1,145^{* *}$ \\
\hline North America & $6,382^{*}$ & $5,726^{*}$ & 0,656 & $5,628^{*}$ & $5,048^{*}$ & $0,580^{* *}$ & $7,164^{*}$ & $6,559^{*}$ & 0,605 \\
\hline Pacific & $8,559 *$ & $6,307 *$ & $2,252^{* *}$ & $7,947^{*}$ & $5,883^{*}$ & $2,063^{*}$ & $8,768^{*}$ & $5,926 *$ & $2,841 * *$ \\
\hline
\end{tabular}

**** and *** denote statistical significance at the $1 \%, 5 \%$ and $10 \%$. Standard deviations and dates are in parentheses. 